\title{
Alleviation of Zn Toxicity in Germinated Wheat Grains (Triticum aestivum L.) by Seed Priming with Defensine Like Protein
}

\author{
Eman E. Selem ${ }^{\#}$ and Deyala M.Naguib \\ Botany Department, Faculty of Science, Zagazig University, Zagazig, Egypt.
}

\begin{abstract}
$\mathbf{T}$
HE AIM of this study is to examine the effect of priming the wheat grains with definsine like protein in a trial to enhance their tolerance of $\mathrm{Zn}$ toxicity. The present technique was performed on two groups of wheat grains that were germinated under different concentrations of $\mathrm{Zn}$. The first group included the non-primed grains and the second group included the primed grains with definsine like proteins which was extracted and purified from fenugreek seeds. Growth and somephysiological parameters of wheat seedlings were determined. Data revealed that increasing $\mathrm{Zn}$ concentrations in the non-primed grains reduced the growth parameters represented by germination ratio and length of both radicle and coleoptile. Also, hydrolysis processes represented by amylase, acid and alkaline phosphatase were significantly decreased, such decrease was accompanied with a decrease in soluble carbohydrates and phosphorus content. Additionally, there was a significant inhibition in the activity of the antioxidant enzymes such as superoxide dismutase, polyphenol oxidase and peroxidase. In contrast, there was an enhancement in the growth process in the definsine primed grains treated with high $\mathrm{Zn}$ concentrations. This was associated with a reduction in the oxidative markers such as malondialdehyde (MDA) and $\mathrm{H}_{2} \mathrm{O}_{2}$ content. Compared with non-primed grains, an improvement in the activity of the antioxidant enzymes and controlling the excess of the ROS were recorded but no significant effect on the hydrolyzing enzymes was found.
\end{abstract}

Keywords: Antioxidant enzymes, Definsine, Germination, Hydrolysis processes, Oxidative stress, $\mathrm{Zn}$ toxicity.

\section{Introduction}

With the expansion of the population, the environmental pollution and toxicity by chemicals become of great concern worldwide. Rapid industrialization and urbanization processes have led to the incorporation of pollutants such as pesticides, petroleum products, acids and heavy metals in the natural resources like soil, water and air thus degrading not only the quality of the environment, but also affecting both plants and animals (Sethy \& Ghosh, 2013). Some heavy metals can be highly toxic when their concentrations exceed threshold value, while others are essential micronutrients for plants in low concentrations, but in higher concentrations they may cause metabolic disorders and growth inhibition for most of the plant species (Kumari et al., 2016). The up-regulation of reactive oxygen species (ROS) induced by Zn stress may contribute to inhibitory effects on the activities of antioxidative enzymes including superoxide dismutase (SOD, EC 1.1.5.1.1), catalase (CAT, EC 1.11.1.6), ascorbate peroxidase (APX, EC
1.11.1.11), glutathione reductase (GR, EC 1.6.4.2) (Li et al., 2013). Another mechanism of heavy metal toxicity is their ability to bind strongly with oxygen, nitrogen and sulfur atoms. This binding affinity is related to free enthalpy of the formation of the product of metal and ligand. Thus, due to these activities, heavy metals can inactivate the enzymes by binding to cysteine residues (Wani et al., 2012).

Zinc phytotoxicity showed a considerable attention because it is a part of the long term utilization of fertilizers, also industry increased its content in the surface soil (Tsonev \& Lidon, 2012). It is known that $\mathrm{Zn}$ can replace $\mathrm{Mg}^{+2}$ ions and it has an important role as functional, structural and regulating cofactor (Molnárová \& Fargašová, 2016).

Priming is a seed treatment before sowing to improve their germination, it includes soaking seeds in a solution where the first two phases of germination (imbibition and activation phases)

"Corresponding author email: eman8_extra8@yahoo.com

Edited by: Prof. Dr. Wedad Kasim, Faculty of Science, Tanta University, Tanta, Egypt.

DOI: $10.21608 /$ ejbo.2018.3837.1179

C2018 National Information and Documentation Center (NIDOC) 
take place without emergence and growth of the radicle. This technique has proven its effectiveness for good crop establishment under stress (Elouaer et al., 2012).

Plant defensins are small, cysteine-rich proteins (45-54 amino acids) that have been isolated from many plant species and tissues (Lay \& Anderson, 2005). A variety of functions have been attributed to plant defensins. While many have antifungal activity, plant defensins have also been described with functions in antibacterial activity, zinc tolerance and blocking of ion channels (Carvalho \& Gomes, 2009 and van der Weerden \& Anderson, 2013).

A defensin like protein from wheat was also found to be induced during cold acclimatization (Koike et al., 2002). Induction of gene expression of plant defensins by drought or salt stresses has also been reported (Yamada et al., 1997 and Maitra \& Cushman, 1998).

Seed germination is one of the most susceptible physiological phenomena in the plant life cycle that is affected by various biotic and abiotic environmental factors (Moosavi et al., 2012), so, any adverse effect on seed germination process would be detrimental for the establishment and healthy growth of seedlings (Donohue et al., 2010).

An excessive $\mathrm{Zn}$ metals in soils can have a negative impact on seed germination, biomass production, root growth, root morphology and architecture. It can also interfere with the activities of many key enzymes related to normal metabolic processes (Dhankhar, 2011). Study on Zn toxicity on Phaseolus vulgaris and Mung bean revealed that the high concentrations of $\mathrm{Zn}$ cuased significant decrease in germination and seedling growth represented in root and shoot length (Hojiboland et al., 2006). In the research of Dhankhar (2011) investigating Vigna mungo (L.), it was observed that the increase in the $\mathrm{Zn}$ concentration from 0.25 to $1.50 \mathrm{mM}$ caused decreasing plumule and radicle lengths. In the experiment of Samuilov et al. (2014) zinc inhibited the growth of both shoots and roots. Also $\mathrm{Zn}$ concentrations of $100-400 \mu \mathrm{g}$ $\mathrm{g}^{-1}$ (soil d.m.) cause significant decrease in root and shoot growth parameters at different developmental stages of Artemisia annua plants (Khudsar et al., 2004).

Thus, this work attempts to apply the technique of priming with definsine to improve the germination of wheat grains under the influence of $\mathrm{Zn}$ toxicity.

\section{Material and Methods}

Extraction and purification of Definsine from Fenugreek seeds

The natural defensin from fenugreek seeds (Trigonella Foenum Graecum), was purified according to Oddepally \& Guruprasad (2015) with some modification as follows, fine flour (100g) was prepared from the fenugreek seeds in a mill. A protein extract was prepared from this flour using $500 \mathrm{ml}$ of extraction buffer $\left(10 \mathrm{mM} \mathrm{Na}_{2} \mathrm{HPO}_{4}, 15 \mathrm{mM}\right.$ $\mathrm{NaH}_{2} \mathrm{PO}_{4}, 100 \mathrm{mM} \mathrm{KCl}, 1.5 \%$ EDTA, pH 5.4) for $2 \mathrm{~h}$ at $4^{\circ} \mathrm{C}$ with constant agitation. The protein extract was centrifuged at $15.000 \mathrm{~g}$ for $15 \mathrm{~min}$. at $25^{\circ} \mathrm{C}$, and the supernatant was fractionated by ammonium sulfate with $70 \%$ relative saturation at $4^{\circ} \mathrm{C}$ for $18 \mathrm{~h}$. After centrifugation under the same conditions, the precipitate was redissolved in distilled water and heated at $80^{\circ} \mathrm{C}$ for $15 \mathrm{~min}$ in a water bath. The heated protein extract was centrifuged at 10,000 $\mathrm{g}$ for $15 \mathrm{~min}$. at $25^{\circ} \mathrm{C}$ and the supernatant was recovered and extensively dialyzed against distilled water for three days and then recovered by freeze drying. For peptides, purification was initially performed on a DEAE-Sepharose column (with $100 \mathrm{ml}$ of resin) equilibrated with $20 \mathrm{mM}$ Tris $-\mathrm{HCl}$ $(\mathrm{pH} 8.0)$ at flow rate of $60 \mathrm{ml} / \mathrm{h}$. The freeze dried protein extract $(50 \mathrm{mg}$ ) was reconstituted in $5 \mathrm{ml}$ of the equilibrium buffer and centrifuged $(16,000 \mathrm{~g}$ for $3 \mathrm{~min}$ at $4^{\circ} \mathrm{C}$ ) and the supernatant was loaded onto the column. A non-retained fraction (D1) was eluted in the equilibrium buffer and examined by SDS protein gel electrophoresis.

Sodium dodecyl sulfate polyacrylamide (SDS) gel electrophoresis (SDS-PAGE) was performed according to the method of Laemmli (1970) as modified by Studienr (1973). One-dimensional SDS-PAGE was run in a mini-gel electrophoresis apparatus (Cleaver Scientific Ltd, OmniPAGE Gel Casting System). Gel was scanned and analyzed with Bio-Rad Video Gel documentation.

\section{Plant material and Zn treatments}

Wheat grains were sterilized in $10 \% \mathrm{Na}$ hypochlorite solution for $10 \mathrm{~min}$, and the grains were washed thoroughly 4-5 times with sterilized distilled water. The grains were divided into two groups; the first was soaked overnight in the prepared definsine solution and the second was soaked in distilled water. 
Five concentrations of $\mathrm{ZnSO}_{4}$ were used in this study. The selected concentrations were $0.0,1.0$, 10,50 and $100 \mathrm{mM}$. For each treatment, the $\mathrm{pH}$ was adjusted to 6.5 .

\section{Determination of germination parameters}

Grain germination test on filter paper was carried out in glass Petri dishes $(15 \mathrm{~cm})$ with three layers of filter paper on the bottom. Each dish contained $10 \mathrm{ml}$ of $\mathrm{ZnSO}_{4}$ solution, and 20 grains, covered by lid. Petri dishes containing the grains with $10 \mathrm{ml}$ of distilled water (free of $\mathrm{Zn}$ solution) served as control. Effluents were applied every alternate day. Petri dishes were incubated at $25^{\circ} \mathrm{C}$ \pm 1 with $16 \mathrm{~h}$ light and $8 \mathrm{~h}$ dark cycles in a growth chamber for 3 days with five replicates and all parameters (germination ratio, root length and coleoptile length) were recorded at 24, 48 and $72 \mathrm{~h}$.

\section{Biochemical study}

The biochemical parameters were determined at 3 different time intervals (24, 48 and $72 \mathrm{~h}$ ), as follows:

\section{Effect on antioxidant machinery}

Determination of hydrogen peroxide $\left(\mathrm{H}_{2} \mathrm{O}_{2}\right)$ content: The content of $\mathrm{H}_{2} \mathrm{O}_{2}$ as a type of reactive oxygen species (ROS) was determined according to the method of Alexievia et al. (2001), in which $1 \mathrm{~g}$ of germinated wheat seedlings was homogenized in $0.1 \%$ trichloroacetic acid (TCA) solution. The homogenate was filtered through Whatman No.1. filter paper, after which $0.5 \mathrm{ml}$ of 100mM K-phosphate buffer ( $\mathrm{pH} \mathrm{6.8)} \mathrm{and} 2 \mathrm{ml}$ reagent $\left(1 \mathrm{M} \mathrm{KI}\right.$ in fresh bidistilled water $\mathrm{H}_{2} \mathrm{O}$ ) were added to $0.5 \mathrm{ml}$ of the leaf extract filtrate. The blank probe consisted of $0.1 \%$ TCA in the absence of leaf extract. The reaction was developed for $1 \mathrm{~h}$ in darkness and the absorbance was measured at $390 \mathrm{~nm}$. The amount of $\mathrm{H}_{2} \mathrm{O}_{2}$ was calculated using a standard curve prepared with known concentrations of $\mathrm{H}_{2} \mathrm{O}_{2}$. The $\mathrm{H}_{2} \mathrm{O}_{2}$ content was expressed as $\mu \mathrm{g} / \mathrm{g}$ fresh weight.

Determination of malonyldialdehyde (MDA) content: MDA determination (Lipid peroxidation product) was applied according to the method described by $\mathrm{Li}$ (2000). $0.2 \mathrm{~g}$ fresh weight was homogenized in $1.5 \mathrm{ml} 5 \%$ TCA. The homogenates were centrifuged at $13000 \mathrm{~g}$ for $20 \mathrm{~min}$. A reaction mixture of the supernatant $(0.5 \mathrm{ml})$ and $1 \mathrm{ml} 20 \%$ TCA and $1 \mathrm{ml} 0.5 \%$ TBA (Thiobarbituric acid) was incubated at $95^{\circ} \mathrm{C}$ in a water bath for $25 \mathrm{~min}$, then cooled immediately before centrifugation. A bsorbance of the supernatants was determined at 450, 532 and 600nm, respectively. Calculation of MDA was based on the following formula:

$$
\operatorname{MDA}(\mu \mathrm{m} / \mathrm{ml})=6.45(\mathrm{~A} 532-\mathrm{A} 600)-0.56 \mathrm{~A} 450
$$

Determination of antioxidant enzymes activity

Total cellular enzyme extraction: Germinated wheat seedlings $(5 \mathrm{~g})$ were homogenized in $1.5 \mathrm{ml}$ extraction buffer (a potassium phosphate buffer $0.1 \mathrm{M}, \mathrm{pH} 7$ in ice cold condition). The homogenates were centrifuged at $5000 \mathrm{rpm}$ for $10 \mathrm{~min}$ at $4{ }^{\circ} \mathrm{C}$ and the supernatant was used as enzymes source (Ma et al., 2012).

\section{Antioxidant enzymes assay}

Assay of superoxide dismutase (SOD): SOD activity was measured by the nitro blue tetrazolium (NBT) reduction method (Beyer \& Fridovich, 1987). Test tubes containing reaction solution with $3 \mathrm{ml}$ of assay buffer, $60 \mu \mathrm{l}$ of crude enzyme and $30 \mu \mathrm{l}$ of riboflavin were illuminated for $7 \mathrm{~min}$ in an aluminum foil lined box containing two Fluorescent lamps at $25^{\circ} \mathrm{C}$. The absorbance of the blank solution and reaction solution was measured with a spectrophotometer at $560 \mathrm{~nm}$. SOD activities were calculated as a following equation:

$$
\text { SOD activity }(\%)=(1-\mathrm{A} / \mathrm{B}) \times 100
$$

where (A) is the absorbance of sample and (B) is the absorbance of blank.

Assay of polyphenol oxidase activity (PPO): It was done according to Beyer \& Fridovich (1987). Five $\mathrm{ml}$ of assay mixture comprising $125 \mu \mathrm{M}$ of phosphate buffer ( $\mathrm{pH} 6.8), 100 \mu \mathrm{M}$ of pyrogallol and $1 \mathrm{ml}$ of crude extract were prepared. After incubation at $25^{\circ} \mathrm{C}$ for $5 \mathrm{~min}$, the reaction was stopped by the addition of $1 \mathrm{ml} 10 \%(\mathrm{v} / \mathrm{v}) \mathrm{H}_{2} \mathrm{SO}_{4}$. The optical density of the produced color was measured spectrophotometricallyat 430nm and the enzyme activity was expressed as the change in the optical density/mg protein/min.

Assay of peroxidase activity (POX): It was done according to Racusen \& Foote (1965). Five $\mathrm{ml}$ of the assay mixture comprising $300 \mu \mathrm{M}$ of phosphate buffer ( $\mathrm{pH}$ 6.8), $50 \mu \mathrm{M}$ catechol, $50 \mu \mathrm{M} \mathrm{H}_{2} \mathrm{O}_{2}$ and $1 \mathrm{ml}$ of crude enzyme extract were prepared. After incubation at $25^{\circ} \mathrm{C}$ for $5 \mathrm{~min}$, the reaction was stopped by the addition of $1 \mathrm{ml} 10 \%(\mathrm{v} / \mathrm{v}) \mathrm{H}_{2} \mathrm{SO}_{4}$. The optical density of the produced color was measured spectrophotometrically at $430 \mathrm{~nm}$ and the 
enzyme activity was expressed as the change in the optical density/mg protein/min.

Determination of hydrolysis processes during germination

Amylase enzyme assay: The amount of starch hydrolyzed by the action of amylases was measured according to Johnson (2007). The amylase activity was expressed as the amount of starch hydrolyzed $\min ^{-1} \mathrm{mg}$ protein ${ }^{-1}$.

Determination of the total soluble carbohydrate content

Carbohydrates were estimated using phenol sulfuric acid method (Dubois et al., 1956).

\section{Acid and alkaline phosphatase assays}

The freshly germinated wheat seedlings $(5 \mathrm{~g})$ were used for enzyme extractions and assays. The activities of all the two enzymes were assayed according to the method of Tominaga \& Takeshi (1974). The specific activity was expressed as nkat $\mathrm{mg}^{-1}$ protein, where one nkat of enzyme activity is defined as one nmol p-nitrophenol liberated $\mathrm{min}^{-1}$.

Determination of the total phosphorus content

The dried powder of germinated wheat seedlings was digested in a mixture of concentrated nitric acid, sulphuric acid and perchloric acid at the ratios 10: 1: 4 , respectively. The volume was made up to a constant volume with distilled water according to the method of Chapman \& Pratt (1978) with certain modifications. Phosphorus content in the digested samples was determined colorimetrically by ascorbic acid method described by Murphy \& Riley (1958). Results were expressed as mg/g dry weight of yielded grains.

\section{Statistical analysis}

Data was presented as the mean of three replications and standard error (SE) bar. Statistical analysis was carried out using ANOVA test and the means were compared by the least significant difference (LSD) test at a significance level of $\mathrm{P} \leq$ 0.05 .

\section{$\underline{\text { Results }}$}

\section{Definsine separation and characterization}

The purification and separation of definsinelike protein from the fenugreek seeds by SDSPAGE revealed the appearance of one protein band has molecular weight $10.7 \mathrm{kDa}$ as indicated in Fig. 1.

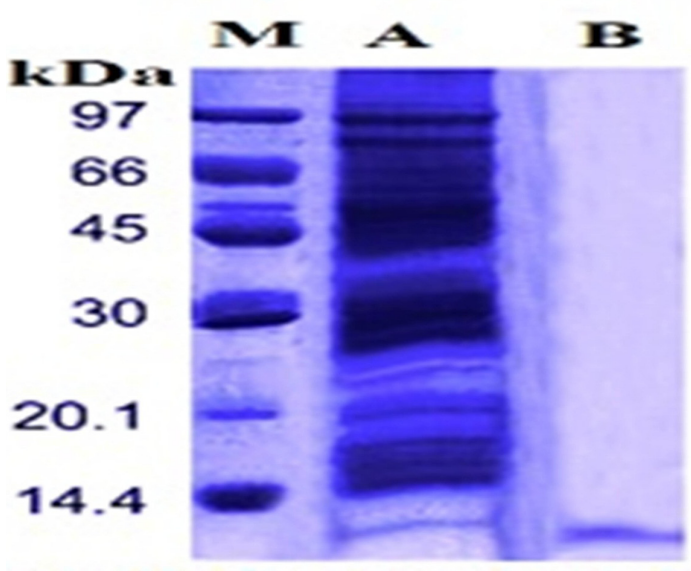

Fig. 1. Protein profile of the bulk fenugreek seeds extract and the purified part as revealed by SDS-polyacrylamide gel (Lane $A=$ Bulk extract, lane $B=$ The purified extract and $M=$ marker).

\section{Effect on germination}

Germination rate of grains treated with the lowest $\mathrm{Zn}$ concentration $(1 \mathrm{mM})$ was unaffected when compared to the control. In contrast, germination was severely inhibited at the high $\mathrm{Zn}$ concentrations $(10,50$ and $100 \mathrm{mM})$ as shown in Table 1. Also, shoot and root lengths of the wheat seedlings were significantly decreased at these high $\mathrm{Zn}$ concentrations, compared to the control. The inhibition in the germination rate was approximately 18,36 and 49\%, respectively under these $\mathrm{Zn}$ concentrations. Upon application of definsine priming method, the germination inhibition rate was decreased with the three concentrations of $\mathrm{Zn}$ to approximately 4.0, 13 and $28 \%$, respectively. This indicates that definsine priming method could alleviate the toxic effect of $\mathrm{Zn}$ on the germination rate.

The data also revealed that, root length of the germinated seedling decreased significantly under the high $\mathrm{Zn}$ concentrations $(10,50$ and $100 \mathrm{mM})$ in a percent of $24.41 \%, 78.71 \%$ and $89.1 \%$, respectively. However, such inhibition was gradually decreased by using definsine priming method recording a percent of $19.5,21.7,33.1 \%$, respectively. Similarly, definsine priming method alleviated the toxic effect of $\mathrm{Zn}$ concentrations on the shoot germination. Under the high $\mathrm{Zn}$ concentrations, the inhibition percentagesof shoot lengthswere 52.7, 74.4 and $75.8 \%$, respectively. Definsine priming led to a reduction in such inhibition percentages of shoot length recording inhibition rates of 12,6, 23.1 and $25.1 \%$, respectively. 
TABLE 1. Effect of wheat grains priming with definsine on germination ratio, root length and coleoptile length of 72h germinated grains under different $\mathrm{Zn}$ concenterations

\begin{tabular}{|c|c|c|c|c|c|c|c|c|c|c|}
\hline \multirow{2}{*}{$\mathrm{Parameter}_{\text {Patments }}$ Treatm } & \multicolumn{5}{|c|}{ Non-primed Grains } & \multicolumn{5}{|c|}{ Definsine Primed Grains } \\
\hline & $\mathbf{0}$ & 1 & 10 & $\mathbf{5 0}$ & 100 & $\mathbf{0}$ & 1 & 10 & 50 & 100 \\
\hline Total germination ratio $\%$ & 97 & 98 & $82 . *$ & $64 *$ & $51 *$ & 100 & 100 & 96 & $87^{*}$. & $72 *$ \\
\hline Root length & 5.12 & 5.1 & $3.87 *$ & $1.09 *$ & $0.56^{*}$ & $5.98 *$ & 5.34 & $4.12 *$ & $4^{*}$ & $3.43^{*}$ \\
\hline coleoptile length & 3.98 & 3.95 & $1.88^{*}$ & $1.02 *$ & $0.96^{*}$ & 4.26 & 4.1 & 3.5 & $3.04 *$ & $2.98^{*}$ \\
\hline
\end{tabular}

-Values are means of 5 replicates.

-Means followed by asterisks are significantly different from the control according to paired-samples $t$ test.

\section{Effect on antioxidant machinery}

In general, the results of this study showed an increase in antioxidant machinery under all concentrations of $\mathrm{Zn}$ in the defensine primed and non-primed germinated grains.

$\mathrm{H}_{2} \mathrm{O}_{2}$ as a reactive oxygen species increased significantly under the high concentrations of $\mathrm{Zn}$. It increased with the percentages of about $672.5 \%, 710.8 \%$ and $1008.22 \%$, respectively after $24 \mathrm{~h}$ from germination and this increase was time- dependent. These percentages of increase were found to be $926.35 \%, 1116.7 \%$ and $1428.45 \%$, respectively after $72 \mathrm{~h}$ from germination, while in the case of definsine priming, the $\mathrm{H}_{2} \mathrm{O}_{2}$ content increased under the high concentrations of $\mathrm{Zn}$ but in a smaller ratio than the non-primed cases. The increase ratios after $24 \mathrm{~h}$ were $145.5 \%, 202.16 \%$ and $203.89 \%$, respectively, but this increase ratios decreased with time, where they were decreased to $25.5 \%, 43.096 \%$ and $46.44 \%$, respectively after $72 \mathrm{~h}$ (Fig. 2).

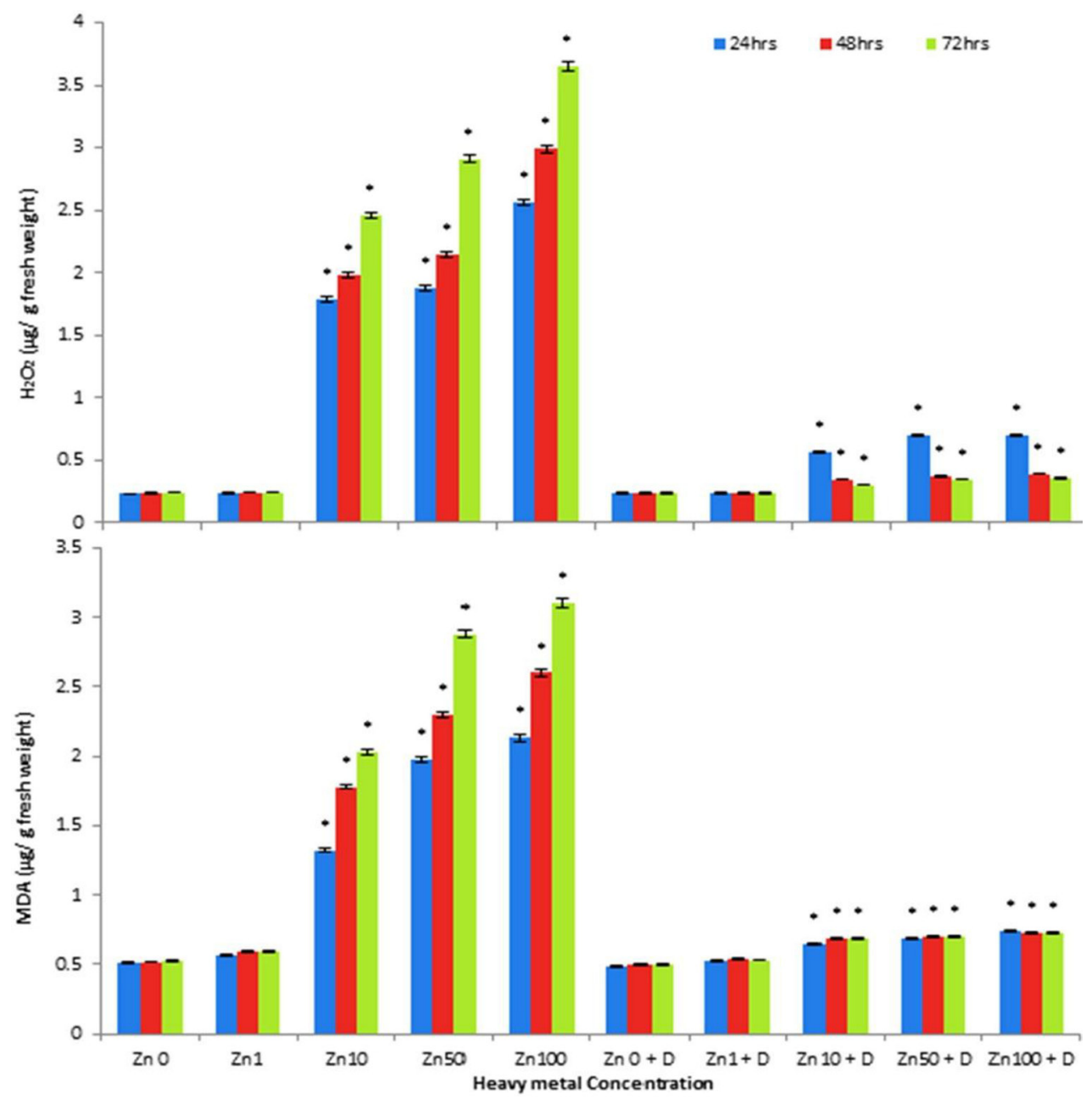

Fig. 2. Effect of wheat grains priming with definsine on $\mathrm{H}_{2} \mathrm{O}_{2}$ and malonyl dialdehyde (MDA) at 24,48 and $72 \mathrm{~h}$ from germination under different concentrations of $\mathrm{Zn}$. (Values are means of 5 replicates. Pars with asterisks are significantly different from the control according to ANOVA test). 
Results presented in Fig. 2 showed that, the MDA increased significantly in the non-primed germinated grains under high concentrations of $\mathrm{Zn}(10,50$ and $100 \mathrm{mM})$. The ratios recorded increased to $290.38,453.8$ and $496.1 \%$, respectively, while the increase ratios in case of the defensine primed germinated grains were $30.7,34.6$ and $38.46 \%$, respectively.
The definsine priming method enhanced the activity of the antioxidant enzymes including superoxide dismutase (SOD), polyphenol oxidase (PPO) and peroxidase (POX) under all $\mathrm{Zn}$ concentrations. The activity of such antioxidant enzymes increased by time in the defensine primed grains, while with the non-primed germinated grains the activity increased with smaller ratio and decreased by time (Fig. 3).

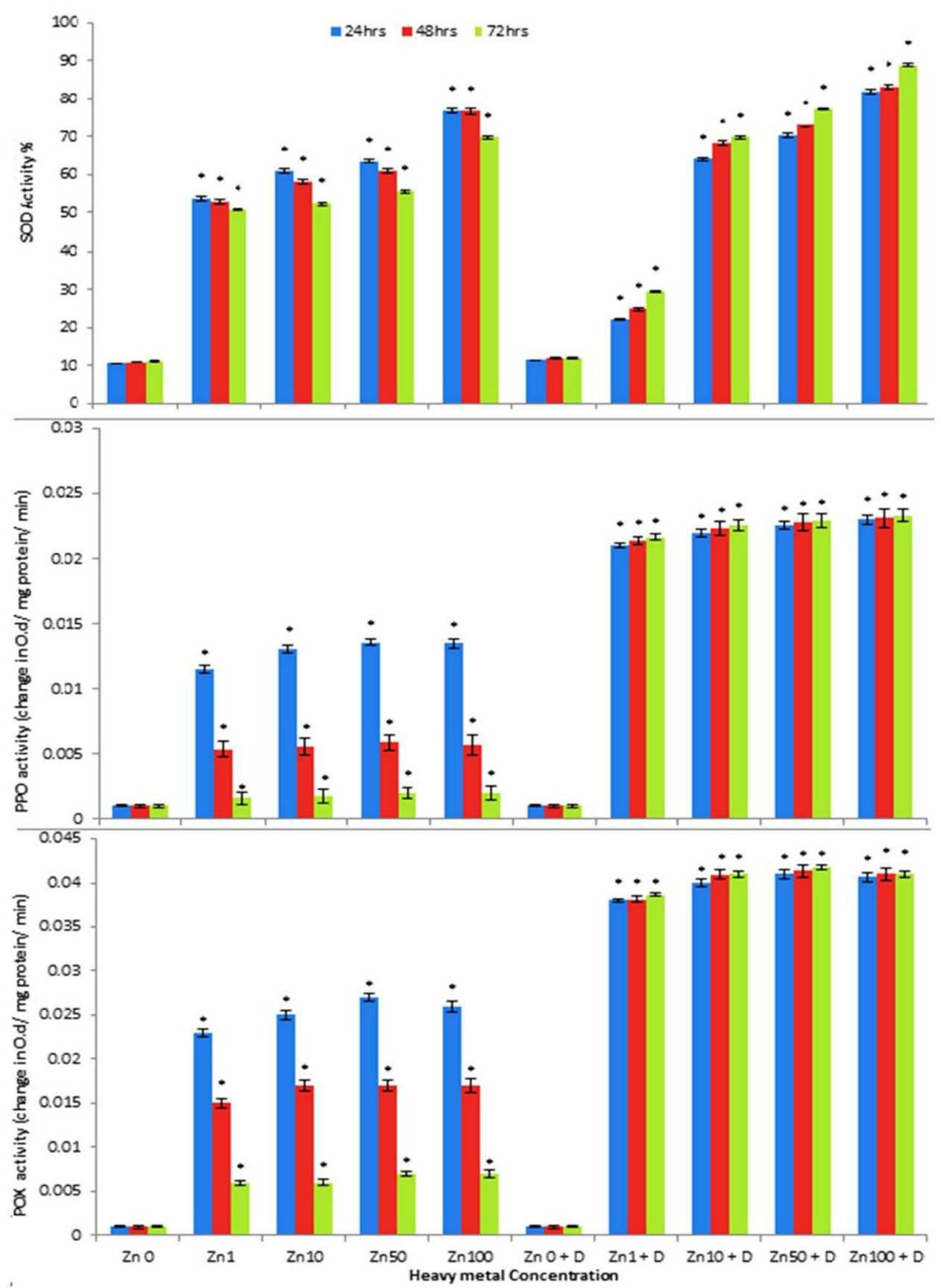

Fig. 3. Effect of wheat grains priming with definsine on antioxidant enzymes (Super oxide Dismutase (SOD), poly phenol oxidase (PPO) and peroxidase (POX)) at 24, 48 and 72h from germination under different concentrations of $\mathrm{Zn}$. (Values are means of 5 replicates. Pars with asterisks are significantly different from the control according to ANOVA test). 


\section{Effect on hydrolysis process}

Priming with definsine significantly enhanced the amylase activity under normal conditions as the activity increased about $16 \%$ than that recorded in non-primed germinated grains. The amylase activity at the low $\mathrm{Zn}$ concentration $(1 \mathrm{mM})$ decreased insignificantly either in definsine primed or non-primed germinated grains. However, the high $\mathrm{Zn}$ concentrations $(10,50$ and $100 \mathrm{mM})$ caused significant decrease in amylase activity in both primed and nonprimed germinated grains. The decrease ratios in the non-primed grains were $53.2 \%, 66.6 \%$ and $83.6 \%$, respectively; while, the amylase activity in the defensine primed germinated grains was significantly decreased when compared to that of the non- primed germinated grains where the recorded ratios were $11.5 \%, 21.5 \%$ and $29.0 \%$, respectively (Fig. 4).

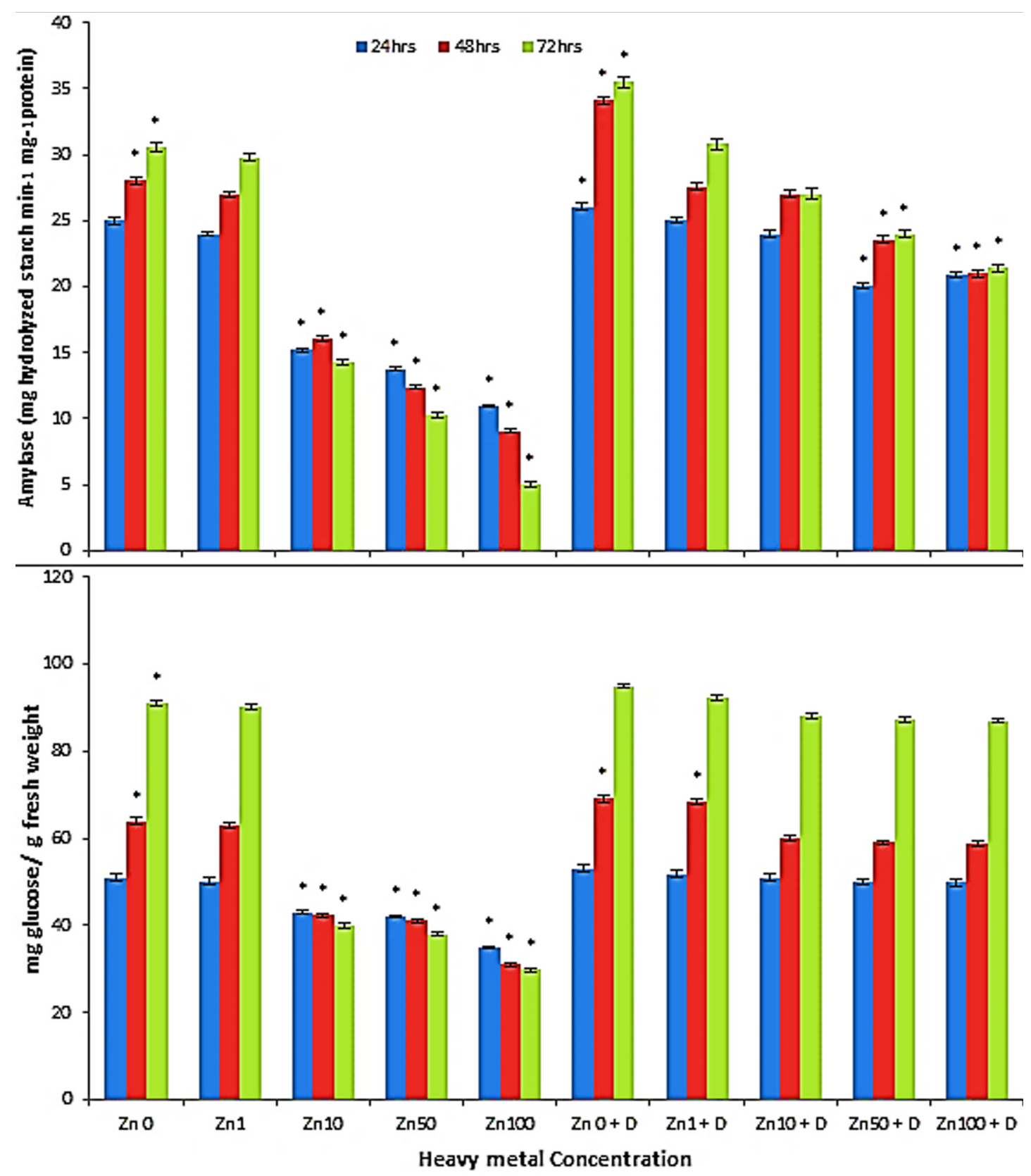

Fig. 4. Effect of wheat grains priming with definsine on amylase activity and carbohydrates content at 24,48 and 72h from germination under different $\mathrm{Zn}$ concentrations. (Values are means of 5 replicates. Pars with asterisks are significantly different from the control according to paired-samples $t$ test). 
As shown in Fig. 4, priming with definsine enhanced the soluble carbohydrates content either in normal germination conditions or under the influence of $\mathrm{Zn}$ concentrations. In response to $\mathrm{Zn}$ concentrations, there was insignificant decrease in the carbohydrate content. However, such decrease was significant in the non-primed germinated grains at high $\mathrm{Zn}$ concentrations recording ratios of $56 \%, 58.2 \%$ and $67.3 \%$, respectively.

Data shown in Fig. 5 indicated that phosphatases activity increased significantly in the defensine primed germinated grains. There was a non-significant decrease in the acid and alkaline phosphatases at high $\mathrm{Zn}$ concentrations $(10,50$ and $100 \mathrm{mM})$. Such decrease was in a small ratio of about $12.05 \%$ and $18.4 \%$, respectively in the acid phosphatase and $9.7 \%$ and $15.6 \%$, respectively in the alkaline phosphatase. However, the phosphatases activity decreased significantly in the non-primed germinated grains recording a ratio of decrease about $61.9 \%$ in acid phosphatase and about $57.8 \%$ in the alkaline phosphatase (Fig .5).

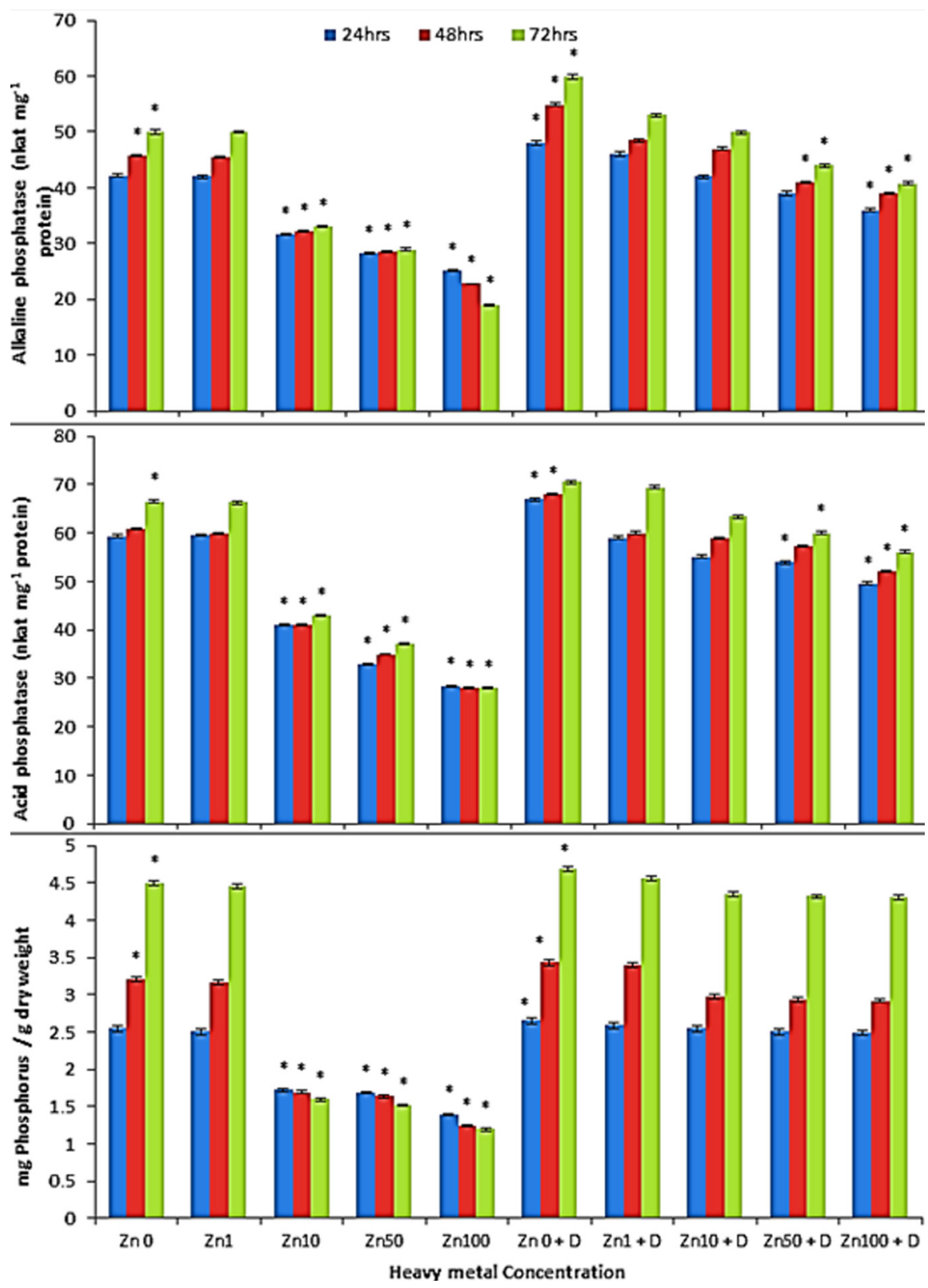

Fig. 5. Effect of wheat grains priming with definsine on acid and alkaline phosphatase and phosphorus content at 24, 48 and 72h from germination under different $\mathrm{Zn}$ concentrations. (Values are means of 5 replicates. Pars with asterisks are significantly different from the control according to paired-samples $t$ test). 
Phosphorus content is related to the activity of the phosphatases. Definsine priming enhanced the soluble phosphate content under normal conditions and $\mathrm{Zn}$ concentrations. However, there was a significant decrease in the phosphorous content in the non-primed germinated grains under high $\mathrm{Zn}$ concentrations (10,50 and $100 \mathrm{mM}$ ) with decrease ratios of about $64.4 \%, 66.26 \%$ and $73.47 \%$, respectively as shown in Fig.5.

\section{Discussion}

The present study was performed to examine the mechanisms of the beneficial effect of defensine priming on the germinated wheat grains exposed to different $\mathrm{Zn}$ concentrations in a trial to alleviate the $\mathrm{Zn}$ phytotoxicity. The life cycle of higher plants begins with seed germination, which depends on perceptions of different environmental stimuli. Seed germination could be affected negatively or positively by many factors including dormancy, embryonic inadequacy, germination inhibitors, water, temperature, gases and light as well as organic and inorganic chemicals, such as zinc, which naturally exist in earth's crust and atmosphere (Srivastava, 2002).

Data of the present study showed that the low concentration of $\mathrm{Zn}(1 \mathrm{mM})$ showed no significant harmful effect on the germination process of wheat plant. This result corroborates with that of Kösesakal \& Ünal (2012) who reported that the low concentrations of $\mathrm{ZnCl}_{2}(1 \mathrm{mM})$ cannot reduce the tomato seeds germination but increases the germination ratio. Such result is in correlation to the fact that $\mathrm{Zn}$ at low concentrations being as one of the most essential micronutrients playing a significant role in many vital metabolic processes. For instance, $\mathrm{Zn}$ is a cofactor for several enzymes, such as anhydrases, dehydrogenases, oxidases and peroxidases (Aravind \& Prasad, 2003). However, in the present results high $\mathrm{Zn}$ concentrations $(10,50$ and $100 \mathrm{mM})$ markedly decreased the germination process in the non-primed germinated wheat grains, such decrease is ensured as the germination process significantly delayed in the non-primed germinated grains, this decrease can be attributed to the toxic oxidative stress caused by the $\mathrm{Zn}$ which significantly appeared in the increase of the oxidative stress markers contents $\left(\mathrm{H}_{2} \mathrm{O}_{2}\right.$ and MDA) under $\mathrm{Zn}$ treatment and their content increased with time. These results are in accordance with those of Molnárová \& Fargašová (2016) who stated that Zn phytotoxicity has come recently into greater focus because it is a part of the long term utilization of fertilizers. Next to this source also industry increased its content in the surface soil. High Zn concentrations create cytotoxic effect on plant growth and metabolism (Arif et al., 2016). Similar results were obtained by Liu et al. (2016) upon germination of Solanum nigrum in the presence of high concentrations of Zn. Also, Munzuroglu \& Geckil (2002) reported that with the increase in $\mathrm{Zn}$ concentration, the germination ratio, coleoptile and hypocotyl length of wheat grains decreased. Excess $\mathrm{Zn}$ causes harmful effects on plants; it inhibits plant growth and root development. Moreover, high $\mathrm{Zn}$ levels could cause cellular oxidative damage and membrane lipid peroxidation in plant cells and affect the activity of many antioxidative enzymes and antioxidant contents in plants (Cherif et al., 2011). However, in the present study the defensine priming enhanced the germination process under Zn- stressed conditions. Similar studies indicated that seed priming has been found a double technology to enhance rapid and uniform emergence and to achieve high vigor and better yields in vegetables and floriculture and some field crops (Lemrasky \& Hosseini, 2012). In addition to better establishment, farmers reported that primed crops grew more vigorously, flowered earlier and yielded higher (Farooq et al., 2008).

Under non-priming conditions, $\mathrm{Zn}$ stress causes excess production of ROS which does not affect the antioxidant enzymes only but also negatively affects the hydrolysis enzymes, as recorded in this study, where the amylase and phosphatases activity decreased as a result of high concentrations of $\mathrm{Zn}$ treatment. This decrease was spontaneously accompanied with decrease in soluble carbohydrates and soluble phosphate contents and so, the germination process was delayed. Similar result was reported by Laware \& Raskar (2014) who showed that upon germination of onion seeds treated with titanium dioxide, the hydrolysis enzymes activity decreased as a result of excess production of the ROS.

The constructive role of the ROS to the enzymes attributed to their ability to cause damage to biomolecules such as lipids, proteins and DNA. These reactions can alter intrinsic membrane properties like fluidity, ion transport, loss of enzyme activity, protein cross-linking, inhibition of protein synthesis, DNA damage, and ultimately resulting in cell death (Sharma et 
al., 2012). However, the present results showed that seed priming using definsine enhanced the germination process under high concentrations of $\mathrm{Zn}$, this could be attributed to the enhancement in the activity of antioxidant enzymes which in turn regulated the ROS production represented in the excess of $\mathrm{H}_{2} \mathrm{O}_{2}$ at the beginning of the germination which plays a messenger role to activate the defense mechanism (Sharma et al., 2012). Zeng et al. (2011) showed that regulation of antioxidative enzymes and control of reactive oxygen species help heavy metal resistance in the hyper accumulator plants.

The current study showed a reduction in the production of MDA and $\mathrm{H}_{2} \mathrm{O}_{2}$ (oxidative stress markers) as a result of defensine priming of wheat grains, these results are generally in agreement with those of Anwaar et al. (2015), who found a decrease in the MDA and $\mathrm{H}_{2} \mathrm{O}_{2}$ and electrolyte leakage in the $\mathrm{Zn}$ tolerant cotton plants suggesting that protection of cotton plants from $\mathrm{Zn}$ toxicity by fighting the induced oxidative damage. Also, Garg \& Kaur (2012) reported that Zn toxicity can be countered by alleviating oxidative stress through up regulation of antioxidant enzymes. Defensine priming of wheat grains in this study resulted in a regulation of antioxidant enzymes and in controlling the excess production of the ROS which protected the hydrolysis enzymes from destruction. Additionally, the activities of amylase and phosphatases were insignificantly affected by high concentrations of $\mathrm{Zn}$ and also in addition to this activity the contents of the soluble carbohydrates and phosphate were not affected. This regulation in hydrolysis process also has a pronounced effect on gibberellin signaling, inducing a change in hormonal balance that results in germination enhancement (Bahin et al., 2011).

The protective role of the definsine like protein against $\mathrm{Zn}$ toxicity has also been studied by Mirouze et al. (2006) who stated that defensins are inducible by $\mathrm{Zn}$. It seems that these defensins play a role in the mechanism of metal tolerance, specifically $\mathrm{Zn}$ mechanism and they suggest that defensins confer $\mathrm{Zn}$ tolerance in plant, like the metal transporters or chelators, defensines found to be involved in metal tolerance and also exist in non-tolerant plants. Two main hypotheses may be proposed to understand the mechanism underlying the role of defensins in plant metal physiology. The first is a $\mathrm{Zn}$ chelation hypothesis, like the metallothioneins, defensins contain cysteine-rich motifs that are potentially involved in metal binding (Cobbett \& Goldsbrough, 2002). The second hypothesis relies on the structure similarity between plant defensins and some channel-blocker peptides such as scorpion btoxins (del Rio-Portilla et al., 2004 and Zhu et al., 2005), which were shown to interfere with divalent cation channels (Carlier et al., 2000 and Castle et al., 2003). A significant amount of work is still necessary to detail the mechanism of action of defensins with respect to $\mathrm{Zn}$ tolerance.

\section{Conclusions}

Results of the present study can ensure that the adverse effects caused by $\mathrm{Zn}$ toxicity in the germinated wheat grains could be alleviated by defensine priming method which increased the $\mathrm{Zn}$ tolerance in wheat germinated grains through alleviating the oxidative stress by up regulation of the antioxidant enzymes. This could be unforeseen role for defensins which opens up new horizons for the investigation of defensine mechanisms of action.

Acknowledgment: Great thank to Prof. Dr. Hegazy Sadik Hegazy; Professor of Plant Physiology, Faculty of Science, Zagazig University for his critical comments and great valuable advices to achieve this work. Sincere thanks also to Prof. Dr. Ahmed A. Ismaiel, Professor of Mycology, Faculty of Science, Zagazig University for revising the manuscript.

\section{$\underline{\text { References }}$}

Alexieva, V., Sergio, I., Mapelli, S. and Karanov, E. (2001) The effect of drought and ultraviolet radiation on growth and stress markars in pea and wheat. Plant Cell Environ. 24, 1337-1344.

Anwaar, S.A, Ali, S., Ali, S., Ishaque, W., Farid, M., Farooq, M.A., Najeeb, U., Abbas, F. and Sharif, M. (2015) Silicon (Si) alleviates cotton (Gossypium hirsutum L.) from zinc ( $\mathrm{Zn}$ ) toxicity stress by limiting $\mathrm{Zn}$ uptake and oxidative damage. Environ Sci. Pollut. Res. Int. 22(5), 3441-50.

Aravind, P. and Prasad, M.N.V. (2003) Zinc alleviates cadmium induced oxidative stress in Ceratophyllum demersum, a fresh water macrophyte. Plant Physiol. Biochem. 41(4), 391-397.

Arif, N., Yadav, V., Singh, S., Singh, S., Ahmad, P., 
Mishra, R.K., Sharma, S., Tripathi, D.K., Dubey, N.K. and Chauhan, D.K. (2016) Plant growth and development vs. high and low levels of plantbeneficial heavy metal ions. Front. Environ. Sci. 4,69 .

Bahin, E., Bailly, C., Sotta, B., Kranner, I., Corbineau, F. and Leymarie, J. (2011) Crosstalk between reactive oxygen species and hormonal signalling pathways regulates grain dormancy in barley. Plant, Cell and Environment, 34, 980-993.

Beyer, Jr.W.F. and Fridovich, I. (1987) Assaying for superoxide dismutase activity: Some large consequences of minor changes in conditions. Anal. Biochem. 161, 559-566.

Castle, N.A., London, D.O., Creech, C., Fajloun, Z., Stocker, J.W. and Sabatier, J.M. (2003) Maurotoxin: A potent inhibitor of intermediate conductance $\mathrm{Ca} 2 \mathrm{p}$-activated potassium channels. Mol. Pharmacol. 63, 409-418.

Carlier, E., Avdonin, V., Geib, S., Fajloun, Z., Kharrat, R., Rochat, H., Sabatier, J.M., Hoshi, T. and DeWaard, M. (2000) Effect of maurotoxin, a four disulfide-bridged toxin from the chactoid scorpion Scorpio maurus, on Shaker Kp channels. J. Peptide Res. 55, 419-427.

Carvalho, Ade O. and Gomes, V.M. (2009) Plant defensins - prospects for the biological functions and biotechnological properties. Peptides, 30(5), $1007-1020$.

Chapman, H.D. and Pratt, P.F. (1978) "Methods of Analysis for Soils, Plant and Water", 50, 309. Univ. Calif., Dept. Agric. Sci., Priced Publication.4034, USA.

Cherif, J., Mediouni, C., Ammar, W.B. and Jemal, F. (2011) Interactions of zinc and cadmium toxicity in their effects on growth and in antioxidative systems in tomato plants (Solanum lycopersicum). J. Environ. Sci. 23(5), 837-844.

Cobbett, C. and Goldsbrough, P. (2002) Phytochelatins and metallothioneins: Roles in heavy metal detoxification and homeostasis. Annu. Rev. Plant Biol. 53, 159-82.

del Rio-Portilla, F., Hernandez-Marin, E., Pimienta, G., Coronas, F.V., Zamudio, F.Z., Rodriguez de la Vega, R.C., Wanke, E. and Possani, L.D. (2004)
NMR solution structure of $\mathrm{Cn} 12$, a novel peptide from the Mexican scorpion Centruroides noxius with a typical betatoxin sequence but with alphalike physiological activity. Eur. J. Biochem. 271, 2504-2516.

Dhankhar, R. (2011) Zinc and copper induced changes in physiological characteristics of Vigna mungo (L.). J. Environ. Biol. 32, 747-751.

Donohue, K., Casas, R.R, Burghardt, L., Kovach, K. and Willis, C.G. (2010) Germination, post germination, adaptation and species ecological ranges. Аnпи. Rev. Ecol. Evol. Syst. 41, 293-319.

Dubois, M., Gilles, K.A., Hamilton, J.K., Rebers, P.A. and Smith, F. (1956) Colorimetric method for determination of sugars and related substances. Anal. Chem. 28, 350-356.

Elouaer, M. Aymen, Zhani, K., Meriem, B.F. and Hannachi, C. (2016) Seed priming for better growth and yield of safflower (Carthamus tinctorius) under saline condition. J. Stress Physiol. Biochem. 8, 135-143.

Farooq, M., Basra, S.M.A., Hafeezu, R. and Saleem, B.A. (2008) Seed priming enhances the performance of late sown wheat (Triticum aestivum L.) byimproving chilling tolerance. J. Agron. Crop Sci. 194, 55-60.

Garg, N. and Kaur, H. (2013) Response of antioxidant enzymes, phytochelatins and glutathione production towards $\mathrm{Cd}$ and $\mathrm{Zn}$ stresses in Cajanus cajan (L.) Millsp. genotypes colonized by arbuscular mycorrhizal fungi. Journal of Agronomy and Crop Science, 199, 118-133.

Hojiboland, R., Niknam, V., Ebrahim-Zadeh, H. and Mozafari, A. (2006) Uptake, transport and chelation of $\mathrm{Cu}$ and $\mathrm{Zn}$ at toxic levels in tolerant and sensitive species from North West of Iran. J. Sci. 17, 203-214.

Johnson, R. (2007) Measuring amylase activity in cereal grains. Colby J. Res. Meth. 9, 11-13.

Koike, M., Okamoto, T., Tsuda, S. and Imaib, R. (2002) A novel plant defensin-like gene of winter wheat is specifically induced during cold acclimation. Biochemical and Biophysical Research Communications, 298, 46-53.

Khudsar, T., Mahmooduzzafar, M. Iqbal and Sairam, 
R.K. (2004) Zinc-induced changes in morphophysiological and biochemical parameters in Artemisia annua. Biol. Plant. 48, 255-260.

Kösesakal, T. and Ünal, M. (2012) Effects of zinc toxicity on seed germination and plant growth in tomato (Lycopersicon esculentum Mill.). Fresenius Environ. Bull. 21, 315-324.

Kumari, M.K.D., Narasimham, V.D., Paramesh, K. and Chandrasekhar, T. (2016) Impacts of cadmium and manganese on in vitro seed germination and seedling growth of horse gram. Ind. J. Plant Sci. 5, 119-125.

Laemmli, U.K. (1970) Cleavage of structural proteins during the assembly of the heat bacteriophage T4. Nature, 227, 680-685.

Laware, S.L. and Shilpa, R. (2014) Effect of titanium dioxide nanoparticles on hydrolytic and antioxidant enzymes during seed germination in onion. Int. J. Curr. Microbiol. App. Sci. 3(7), 749-760.

Lay, F.T. and Anderson, M.A. (2005) Defensinscomponents of the innate immune system in plants. Curr. Protein Pept. Sci. 6, 85-101.

Lemrasky, M.G. and Hosseini, S.Z. (2012) Effect of seed priming on the germination behavior of wheat. Int. J. Agri. Crop Sci. 4, 564-567.

Li, H.S. (2000) "Principles and Techniques of Plant Physiological Biochemical Experiment". Lipid peroxidation, pp. 260-263. Higher Education Press, Beijing, China.

Li, X., Yang, Y., Jia, L., Chen, H. and Wei, X. (2013) Zinc-induced oxidative damage, antioxidant enzyme response and proline metabolism in roots and leaves of wheat plants. Ecotoxicol. Environ. Saf. 89, 150-7.

Liu, X., Chen, J., Wang, G.H., Wang, W.H., Shen, Z.J., Luo, M.R. and Zheng, H.L. (2016) Hydrogen sulfide alleviates zinc toxicity by reducing zinc uptake and regulating genes expression of antioxidative enzymes and metallothioneins in roots of the cadmium/zinc hyperaccumulator Solanum nigrum L. Plant Soil. 400, 177-192.

Ma, H., Song, L., Shu, Y., Wang, S., Niu, J., Wang, Z., Yu, T., Gu, W. and Ma, H. (2012) Comparative proteomic analysis of plants leaves of different salt tolerant soybean genotypes. J. Proteomics, $\mathbf{7 5}$, 1529-1546.

Maitra, N. and Cushman, J.C. (1998) Characterization of a drought-induced soybean cDNA encoding a plant defensin. Plant Physiol. 118, 1536.

Mirouze, M., Sels, J., Richard, O., Czernic, P., Loubet, S. and Jacquier, A. (2006) A putative novel role for plant defensins: A defensin from the zinc hyperaccumulating plant, Arabidopsis halleri, confers zinc tolerance. Plant J. 47, 329-42.

Molnárová, M. and Fargašová, A. (2016) Se (IV), Se (VI), $\mathrm{Cu}$ and $\mathrm{Zn}$ phytotoxicity in correlation to their accumulation in Sinapis alba L. seedlings. Plant Root. 10, 11-20.

Moosavi, S.A., Gharineh, M.H., Afshari, R.T. and Ebrahimi, A. (2012) Effects of some heavy metals on seed germination characteristics of canola (Barassica napus), wheat (Triticum aestivum) and safflower (Carthamus tinctorious) to evaluate phytoremediation potential of these crops. J. Agri. Sci. 4, 11-19.

Munzuroglu, O. and Geckil, H. (2002) Effects of metals on seed germination, root elongation and coleoptile and hypocotyl growth in Triticum aestivum and Cucumis sativus. Arch. Environ. Contam. Toxicol. 43, 203-213.

Murphy, J. and Riley, J.P. (1958) Single-solution method for the determination of soluble phosphate in sea water. J. Mar. Biol. Assoc. 37, 9-14.

Oddepally, R. and Guruprasad, L. (2015) Isolation, purification and characterization of a stable defensin-like antifungal peptide from Trigonella foenum-graecum (fenugreek) seeds. Biochem. (Moscow). 80, 332-342.

Racusen, D. and Foote, M. (1965) Protein synthesis in dark grown bean leaves. Can. Bot. 43, 817-824.

Samuilov, S., Đunisijević Bojović, D., Đukić, M. and Raković, J. (2014) The effect of elevated Zn concentrations on seed germination and young seedling growth of Ailanthus altissima (Mill.) Swingle. Bull.Fac. For. 110, 145-158.

Sethy, S.K. and Ghosh, S. (2013) Heavy metal toxicity in seeds. JNSBM, 4, 272-275. 
Sharma, P., BhushanJha, A., Dubey, R. and Pessarakli, M. (2012) Reactive oxygen species, oxidative damage and antioxidative defense mechanism in plants under stressful conditions. J. Bot. 2012, $1-26$.

Srivastava, L.M. (2002)"Plant Growth and Development Hormones and Environment". Academic Press, China.

Studienr, F.W. (1973) Analysis of bacteriophage T7 early RNAs and proteins of slab gels. J. Mol. Biol. 79, 237-248.

Swathi, T.S.K. Jami and Kirti, P.B.A. (2009) Defensin gene of Indian mustard is stress induced. J. Plant Biochemistry and Biotechnology, 18(2), 221-224.

Tominaga, N. and Takeshi, M. (1974) A sulfite dependent acid phosphatase of Thiobacillus thioxidans. J. Biochem. 76, 419-428.

Tsonev, T. and Lidon, F.J.C. (2012) Zinc in plants - An overview. Emir. J. Food Agric. 24, 322-333

Van der Weerden, N.L. and Anderson, M.A. (2013) Plant defensins: common fold, multiple functions.
Fungal Biol Rev. 26, 121-131.

Wani, S.P., Dixin, Y., Li, Z., Dar, W.D. and Chander, G. (2012) Enhancing agricultural productivity and rural incomes through sustainable use of natural resources in the semi-arid tropics. J. Sci. Food Agric. 92, 1054-1063.

Yamada, S., Komori, T. and Imaseki, H. (1997) cDNA cloning of $\gamma$-thionin from Nicotiana excelsior. Plant Physiol. 115, 314.

Zeng, X.W., Ma, L.Q., Qiu, R.L. and Tang, Y.T. (2011) Effects of $\mathrm{Zn}$ on plant tolerance and nonprotein thiol accumulation in Zn Hyperaccumulator Arabispa niculata Franch. Environ. Exp. Bot. 70, 227-232.

Zhu, S., Gaoand, B. and Tytgat, J. (2005) Phylogenetic distribution, functional epitopes and evolution of the Csab superfamily. Cell Mol. Life Sci. 62, 2257-2269.

(Received 14/ 5/2018; accepted 25/7/2018)

\section{التخفيف من سمية الزنك في حبوب القمح الناميه (Triticum aestivum L.) بواسطة معامله البذور بالديفينسين ايمان السيد سليم و ديالا محمد نجيب قسم النبات ـ كلية العلوم - جامعة الزيقازيق ـ الزقازيق ـ مصر.}

\footnotetext{
تهدف هذه الدر اسه لإختبار تأثير طريقة غمر حبوب نبات القمح قبل الزر اعة بشبيه البروتين الافينسين لتحسين

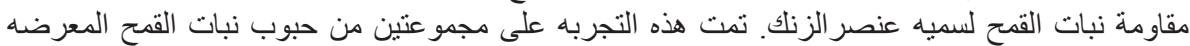

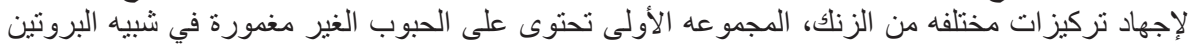

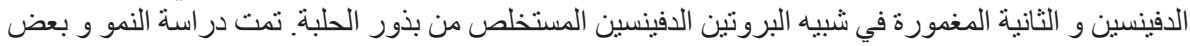

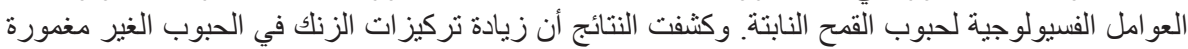

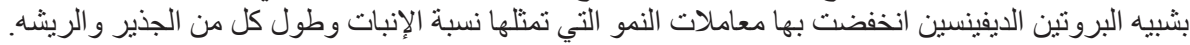

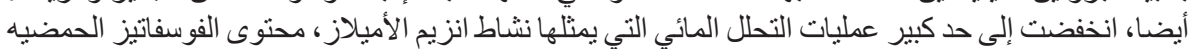

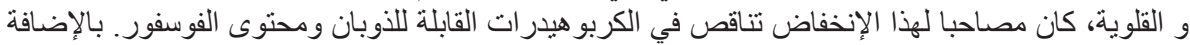

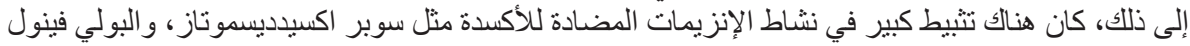

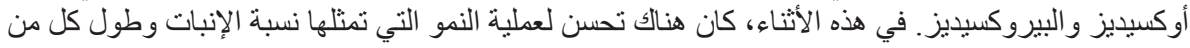

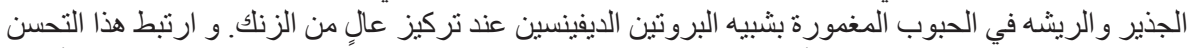

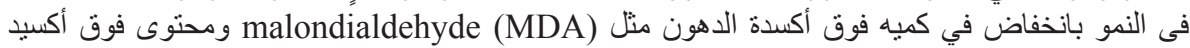

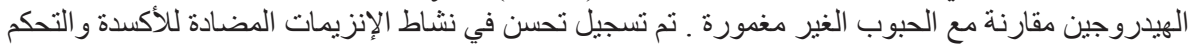
في الفائض من ROS و لم يتم تسجيل أى تانثير كبير على الإنزيمات المحلله.
} 